\title{
Differential Metabolic and Biological Profiles of Lychnophora ericoides Mart. (Asteraceae) from Different Localities in the Brazilian "campos rupestres"
}

\author{
Leonardo Gobbo-Neto, ${ }^{a}$ Thais Guaratini, ${ }^{b}$ Cláudia Pessoa, ${ }^{c}$ Manoel O. de Moraes, ${ }^{c}$ \\ Letícia V. Costa-Lotufo, ${ }^{c}$ Roberto F. Vieira, ${ }^{d}$ Pio Colepicolo ${ }^{b}$ and Norberto P. Lopes ${ }^{*, a}$
} ${ }^{a}$ Departamento de Física e Química, Faculdade de Ciências Farmacêuticas de Ribeirão Preto,
Universidade de São Paulo, 14040-903 Ribeirão Preto-SP, Brazil

${ }^{b}$ Instituto de Química, Universidade de São Paulo, 05508-900 São Paulo-SP, Brazil

${ }^{c}$ Departamento de Fisiologia e Farmacologia, Faculdade de Medicina, Universidade Federal do Ceará, 60431-970 Fortaleza-CE, Brazil

${ }^{d}$ Embrapa Recursos Genéticos e Biotecnologia, Parque Estação Biológica, 70770-900 Brasília-DF, Brazil

Este artigo descreve a caracterização por CLAE-DAD-EM/EM e CLAE-DEC dos perfis de metabólitos secundários de extratos das folhas de Lychnophora ericoides Mart. de diferentes procedências e suas propriedades citotóxicas e antioxidantes. Extratos foliares de populações representando sete diferentes localidades foram avaliados quanto à atividade antioxidante pelo sistema DPPH e à atividade citotóxica em três linhagens tumorais. Os extratos foram eletroquimicamente caracterizados por CLAE-DEC e seus metabólitos secundários majoritários foram identificados por CLAE-DAD-EM e CLAE-DAD-EM/EM. Um metabolismo secundário defensivo amplificado, juntamente com as mais altas bioatividades antioxidantes e citotóxicas, foi encontrado para as plantas coletadas na interface entre dois tipos de vegetação. Estes resultados fornecem apoio adicional para a hipótese de que plantas ocorrendo na interface entre dois ecossistemas podem ser estimuladas a amplificar sua produção e armazenamento de metabólitos secundários defensivos, devido ao maior número de influências ambientais.

This paper reports HPLC-DAD-MS/MS and HPLC-ECD characterisation of secondary metabolite profiles of Lychnophora ericoides Mart. leaf extracts from different provenances and their cytotoxic and antioxidant properties. Leaf extracts from populations representing seven different locations were evaluated for antioxidant activity by the DPPH radical scavenging system and activity towards cellular growth in three tumor cell lines. The extracts were electrochemically analysed by HPLC-ECD and their main secondary metabolites were identified by HPLC-DAD-MS and HPLC-DAD-MS/MS. An amplified defensive secondary chemistry, together with maximal cytotoxic and antioxidant bioactivities, were found for plants collected at the interface between two types of forest. These findings furnish additional support for the hypothesis that plants occurring at the interface between two forests ecosystems might be stimulated to amplify their own production and storage of defensive secondary metabolites due to the greater number of environmental influences.

Keywords: Lychnophora ericoides, secondary metabolite infra-specific variation, hyphenated techniques, cytotoxic activity, antioxidant activity

\section{Introduction}

The genus Lychnophora (Asteraceae, Vernonieae) is restricted to the Brazilian "cerrado", the Brazilian

*e-mail: npelopes@fcfrp.usp.br savannas..$^{1,2}$ Traditional medicine employs alcohol and water-alcohol preparations of leaves and root powder from several Lychnophora species for the treatment of wounds, inflammation and pain. ${ }^{3,4}$ Among Lychnophora species, L. ericoides Mart. is the most widely used in traditional medicine. ${ }^{3,4}$ This species occurs in small and well delimited 
microendemic populations, usually containing between 20 50 adult individuals in a $100-200 \mathrm{~m}^{2}$ area, and occurring in a particular type of high altitude, rocky field found in the Brazilian "cerrado". These fields are known as "campos rupestres". ${ }^{1}$

Previous phytochemical investigation of $L$. ericoides leaves yielded mainly sesquiterpene lactones (STL), caffeoylquinic acids, di- $C$-glucosylflavones and flavonoid aglycones $^{3-7}$ (Figure 1). In vivo experiments indicated that vicenin-2 was the main anti-inflammatory compound in leaves $^{3}$ and that lignans $s^{8}$ and caffeoylquinic acid derivatives, the latter isolated from both leaves and roots, ${ }^{4,6}$ were the main analgesic compounds.

Several biological activities have been attributed to STL. ${ }^{9-11}$ Anti-inflammatory and cytotoxic activities, among others, have been shown to be related to the $\alpha, \beta$-unsaturated $\gamma$-lactone moiety which can behave as Michael-acceptor for example, with cystein amino acid residues. ${ }^{12}$ There is some evidence for an ecological role for STL in plants, like their effectiveness as insect antifeedants, due to their bitter taste and cytotoxicity ${ }^{13-15}$ and potential allelopathic activities. ${ }^{16}$

As mentioned above, the Lychnophora genus is endemic to the Brazilian "cerrado", where high exposure to UV light, an alternation between long periods of drought and rain and periodic burnings are regional characteristics. Coevolution of these plants with such peculiar environmental characteristics, as well as endemic herbivores and local flora, certainly led to the establishment of protection mechanisms against the deleterious effects of these and other stressful environmental conditions, for instance by the accumulation of cytotoxic compounds and UV protective pigments, such as STL and flavonoids, respectively.9-11,17,18

The eminent natural products chemist Professor Otto R. Gottlieb has presented at several conferences the idea of

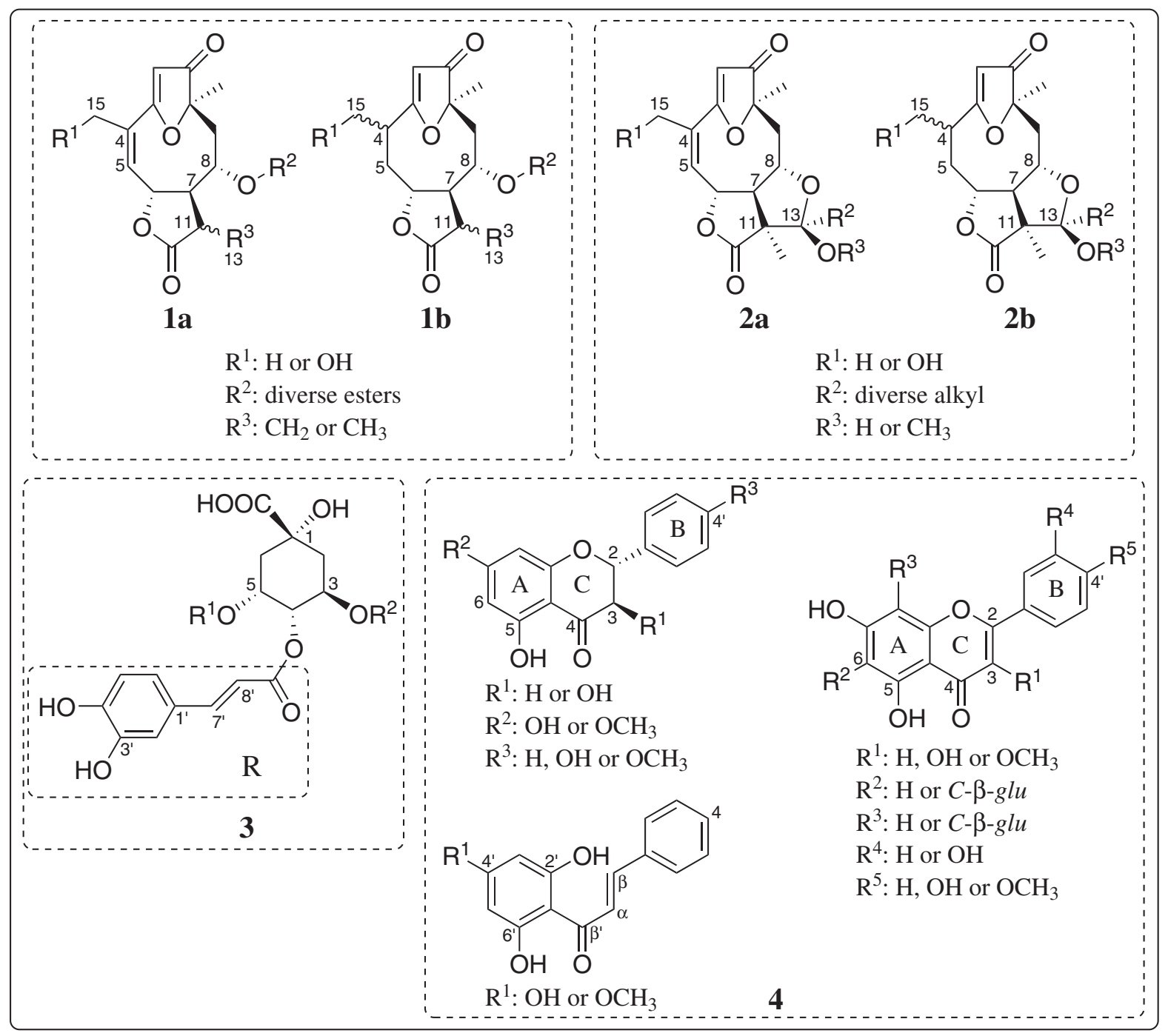

Figure 1. Classes of the major secondary metabolites occurring in leaf extracts of Lychnophora ericoides. 1a and 1b goyasenzolide moiety STL; 2a and 2b eremantholide moiety STL; $\mathbf{3}$ caffeoylquinic acid derivatives; $\mathbf{4}$ flavonoids. 
the influence of forest boundaries on secondary metabolite storage. According to this idea, plants occurring at the frontier between two different types of forest could be stimulated to amplify their own production and storage of defensive secondary metabolites, due to the greater number of environmental influences. ${ }^{19-21}$

In this study, the major secondary metabolites in L. ericoides leaf extracts were characterised by means of HPLC-DAD-MS/MS. ${ }^{22}$ Specimens from different environments were analysed using this technique, leading to the establishment of secondary metabolite chemical profiles. The extracts were also analysed by HPLC-ECD, which provides evidence regarding the mechanisms of biological electron-transfer processes and can be useful for estimation of the antioxidant activity of extracts. Additionally, all specimens were assayed for cytotoxic and antioxidant activities and the results were correlated with the different eco-geographical origins and secondary metabolite composition.

\section{Results and Discussion}

Seven populations of $L$. ericoides were accessed and their cytotoxic and antioxidant activities and chemical profiles were characterised. Six of the analysed populations (those from São José da Barra, São João Batista do Glória, Cocalzinho, Capitólio, Pirenópolis and Delfinópolis) were growing in typical "campus rupestris" fields. The latter are characterised by sandy and rocky soil with a predominantly grassy and herbaceous, dicotyledonous vegetation, presenting very scattered shrubs (among them, Lychnophora spp. and Eremanthus spp.) and almost no presence of trees. The other population (from Ibiraci) was the only one growing in a visible transitional zone between the typical "campos rupestres" and a semi-deciduous forest, the latter characterised by a less sandy soil and a much more dense vegetation with a great predominance of trees and shrubs over grasses and herbs.

In the first screening for compositional divergence in defensive secondary metabolites between specimens from different eco-geographical environments, L. ericoides leaf extracts representing each location were analysed for possible differences in their cytotoxic effects. As shown in Table 1, the extract from Ibiraci exhibited the strongest cytotoxic activity in all the cell lines evaluated, while extracts from the other localities presented insignificant or very low cytotoxicity in general.

Several STL are known to be active against cancer cell lines and compounds of this class are also well known to be plant defence products..$^{9-11,13-16}$ Furthermore, they are among the major secondary metabolites previously isolated from L. ericoides. ${ }^{5,7}$ Since the Ibiraci population is the only one among the plants studied that occupies the border between two different types of forests ("cerrado" and semi-deciduous forest), this suggests a possible relationship between its higher cytotoxic activity and an amplification of its secondary metabolite biosynthesis, especially of STL, in agreement with the proposal that plants under environmental pressure could synthesise and store more defensive secondary metabolites.

Table 1. Cytotoxic and antioxidant (DPPH Radical Scavenging System) activity of Lychnophora ericoides leaves extracts from different provenances of Minas Gerais (MG) and Goiás (GO) states. Data for cytotoxicity are presented as growth inhibition (mean \pm SEM) for breast (MDA-MB-435), colon (HCT-8) and central nervous system (SF-295) cancer cells from three independent experiments. Doxorubicin was used as positive control. Antioxidant activities are presented as the minimum concentration of each sample $(\mu \mathrm{g} \mathrm{mL}-1)$ required to inhibit $30 \%$ of the DPPH radical $\left(\mathrm{IC}_{30}\right)$. Rutin was used as positive control. HPLC-ECD total peak areas were calculated by summing the peak areas of chromatograms obtained at 100, 250 and $500 \mathrm{mV}$. The letters indicate each location (A: Ibiraci; B: São José da Barra; C: São João Batista do Glória; D: Cocalzinho; E: Capitólio; F: Pirenópolis; G: Delfinópolis).

\begin{tabular}{|c|c|c|c|c|c|}
\hline \multirow{2}{*}{ Provenance } & \multicolumn{3}{|c|}{ GI $/ \%($ mean \pm SEM $)$} & \multirow{2}{*}{$\begin{array}{c}\mathrm{IC}_{30} /(\mathrm{DPPH} \\
\text { inhibition) }\end{array}$} & \multirow{2}{*}{$\begin{array}{c}\text { HPLC-ECD } \\
\text { peak areas sum }\end{array}$} \\
\hline & MDA-MB-435 & HCT-8 & SF-295 & & \\
\hline A & $104.06 \pm 1.06$ & $91.70 \pm 8.41$ & $95.54 \pm 0.46$ & $15.7 \pm 0.4$ & 92416840 \\
\hline B & $-8.05 \pm 12.54$ & $-7.48 \pm 5.85$ & $-27.49 \pm 18.82$ & $21.2 \pm 1.1$ & 87080097 \\
\hline $\mathrm{C}$ & $8.98 \pm 7.05$ & $-19.54 \pm 11.46$ & $-9.67 \pm 12.48$ & $35.4 \pm 1.7$ & 67803321 \\
\hline $\mathrm{D}$ & $21.95 \pm 20.31$ & $9.89 \pm 16.54$ & $8.73 \pm 23.04$ & $26.0 \pm 1.3$ & 76794233 \\
\hline $\mathrm{E}$ & $5.49 \pm 6.84$ & $-37.87 \pm 9.85$ & $16.00 \pm 12.95$ & $23.7 \pm 0.5$ & 85618072 \\
\hline $\mathrm{F}$ & $23.02 \pm 6.70$ & $-16.73 \pm 6.51$ & $-19.16 \pm 8.38$ & $14.7 \pm 1.1$ & 103786221 \\
\hline G & $11.76 \pm 7.56$ & $-17.93 \pm 7.82$ & $-16.64 \pm 14.89$ & $33.5 \pm 2.0$ & 72123140 \\
\hline doxorubicin & $109.69 \pm 0.14$ & $97.73 \pm 0.23$ & $92.84 \pm 0.35$ & - & - \\
\hline rutin & - & - & - & $3.9 \pm 0.6$ & - \\
\hline
\end{tabular}

GI: growth inhibition. 
For better characterisation of the specimens' bioactivity differences, antioxidant assays and HPLC-ECD analyses were also performed. In the antioxidant assay using the DPPH radical scavenging system, extracts from specimens collected at Ibiraci and Pirenópolis showed the highest activity (no significant statistical difference between them), while extracts from São João Batista do Glória and Delfinópolis (not statistically different from each other) exhibited the lowest antioxidant activity (Table 1). The results mean that lower concentrations of extracts from Ibiraci and Pirenópolis plants are need to inhibit the same concentration of DPPH radical.

Electrochemical studies can provide evidence on the mechanisms of biological electron-transfer processes, ${ }^{23,24}$ and one obvious application is in electroanalytical studies of antioxidants. A linear correlation has been reported between the antioxidant activity of fruit and vegetables and the total electrochemical responses obtained by HPLC$\mathrm{ECD},{ }^{25}$ i.e., the sum of all peak areas in a given HPLC-ECD chromatogram is proportional to the total amount and total concentration of electroactive compounds present in the analyte (extract). As a reducing agent (i.e., an electroactive compound) can generally be an antioxidant, this sum can be used as a preliminary screening to find antioxidant activity of complex mixtures, such as plant extracts, especially when analysed at low potential..$^{25,26}$

In this way, extracts from plants collected in the different regions were analysed by HPLC-ECD to verify their electrochemical behaviour. For each sample of L. ericoides, chromatograms were obtained at different applied potentials, and the peak areas summed. ${ }^{27}$ Different HPLC-ECD chromatographic profiles were obtained (exemplified in Figure S1 at Supplementary Information online) and, in agreement with the DPPH assay, extracts from specimens collected at Ibiraci and Pirenópolis showed the highest total peak areas (corresponding to the highest electroactive compounds content) and a higher response ${ }^{25}$ was observed at lower potentials for these samples (Table 1). When comparing chromatograms of all samples, major qualitative and quantitative variations could be seen for compounds eluted before $25 \mathrm{~min}$, which mainly represent antioxidant molecules, such as chlorogenic acid derivatives and di- $C$-glucosylflavones, which are known for their antioxidant activity (peak identification will be discussed below). ${ }^{3,28,29}$ Thus, the variation in results obtained with DPPH assay for the different extracts might be explained by differences in the total amount of chlorogenic acid derivatives and di- $C$-glucosylflavones in the extracts, as will be discussed bellow.

For the chemical characterisation and differentiation of the extracts from different localities, HPLC-DAD-MS and HPLC-DAD-MS/MS analyses ${ }^{22}$ using the positive ionisation mode were performed for obtaining a fingerprint of $L$. ericoides secondary metabolites. The MS TIC chromatograms acquired for $L$. ericoides extracts from three different sites (Figure 2) illustrate the HPLC-DAD-MS method. Identification of the major chromatographic peaks was performed by comparison of the data obtained by HPLC-DAD-MS/MS analyses (available in Table S1 as Supplementary Information online) and data available in the literature and/or obtained for authentic standards, as follows. Based on UV spectral data, peaks 1 and 4-11 were ascribed to chlorogenic acid derivatives; peaks 2 and 3 to flavones; peaks 12-18, 20, 21 and 23 to STL; peaks 19 and 25 to chalcones and peaks 22, 26 and 27 to either flavanones or dihydroflavonols. Possible molecular formulae calculated from accurate masses obtained from the TIC MS chromatogram, together with the previously reported secondary chemistry of $L$. ericoides, ${ }^{3,5-7}$ were then used to suggest secondary metabolites for each peak, which were confirmed with co-injection of standards, when available. Finally, HPLC-DAD-MS/MS data were used to confirm and/or assign the chemical structures for each peak, when possible.

By co-injection (co-elution) with authentic standards in the developed analyses method, peaks 1, 4-6 and 11 (Figure 2) were identified as 5-O-E-caffeoylquinic, 3,4-, 3,5- and 4,5-di-O-E-caffeoylquinic and 3,4,5-tri- $O-E$ caffeoylquinic acids, respectively. The measured accurate masses of their protonated molecules $\left([\mathrm{M}+\mathrm{H}]^{+}\right)$and fragmentation patterns were also in accordance with the chemical structures of those compounds..$^{30}$ Peaks 7-10 (Figure 2) exhibited UV spectra nearly identical to those of the caffeoylquinic acids, and their calculated molecular formulae $\left(\mathrm{C}_{26} \mathrm{H}_{26} \mathrm{O}_{12}\right.$, considering the base peak in MS-TIC chromatogram as the protonated molecule) suggested a methyl group in addition to the di-caffeoylquinic acids chemical structure. The presence of $m / z 163$ (which was also observed in the product ion spectra of all the caffeoylquinic acid derivatives identified above) and $\mathrm{m} / \mathrm{z} 177$ in the product ion spectra of these compounds evidenced, respectively, the presence of both a caffeoyl and a feruloyl moiety, leading to the assignment of peaks 7-10 to caffeoylferuloylquinic acid positional isomers.

Chromatographic peaks 2 and 3 (Figure 2) were identified as the di-C-glucosylflavones 6,8 -di- $C$ - $\beta$-glucosylapigenin (vicenin-2) and 6,8-di-C- $\beta$-glucosylchrysin, respectively, due to the co-elution with standards of these compounds previously isolated from L. ericoides, as stated in GobboNeto et al. ${ }^{31}$ Their measured accurate masses are in accordance with the calculated exact molecular masses of the respective protonated molecules, and the fragmentation 


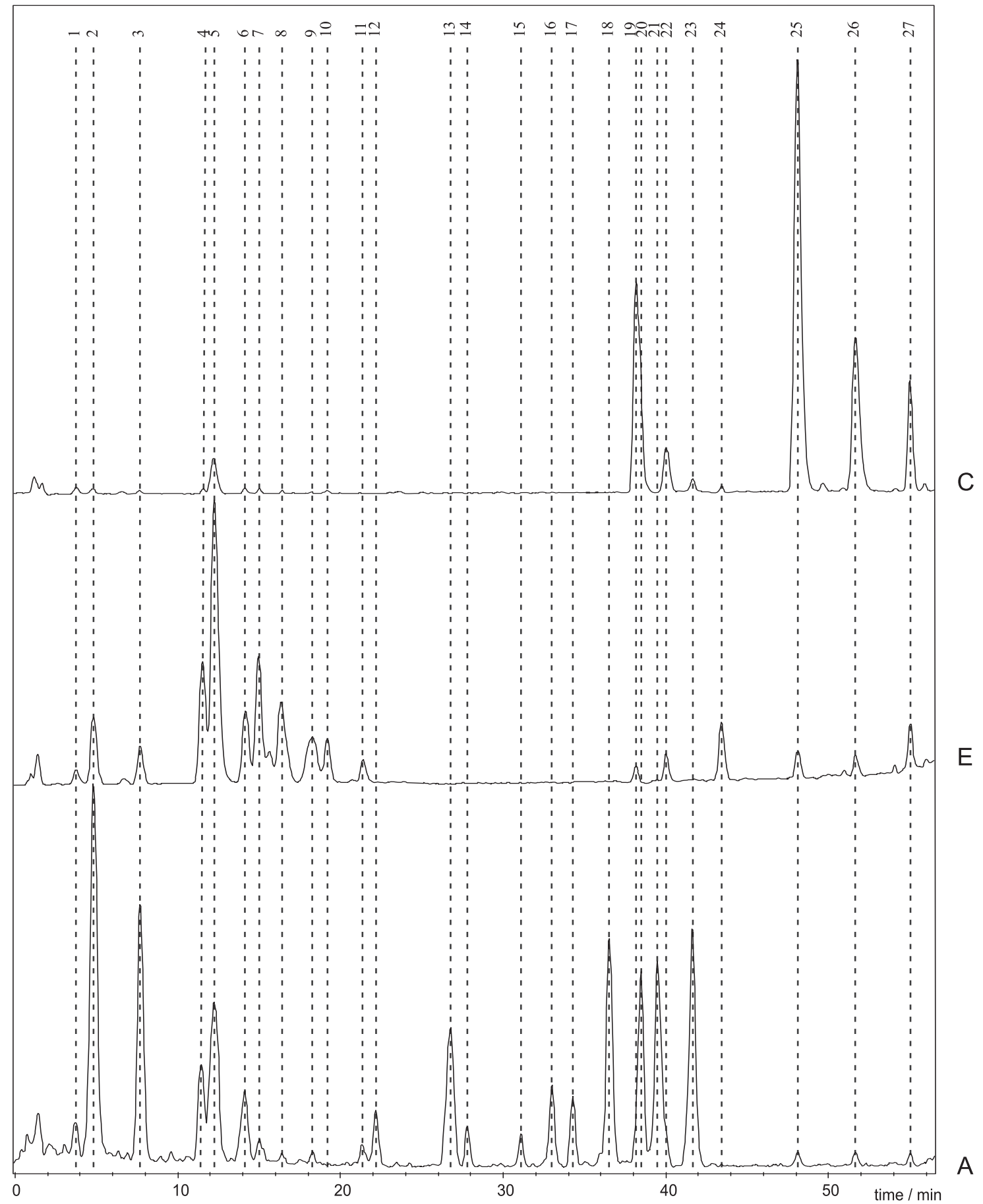

Figure 2. TIC-MS chromatographic profile of Lychnophora ericoides extracts from São João Batista do Glória (C, top), Capitólio (E, middle) and Ibiraci (A, bottom) obtained by HPLC-DAD-MS in the positive ionisation mode, all under the same experimental conditions. Peak number identities and spectral properties are available in Table S1 as Supplementary Information online.

patterns $^{32}$ and UV spectra matched those obtained for authentic standards.

Chromatographic peak 26 (Figure 2) was identified as the flavanone pinostrobin by comparison of retention time (co-injection) and UV spectrum with data obtained from an authentic standard previously isolated from L. ericoides. ${ }^{6}$ Moreover, the fragmentation pattern observed in the product ion spectrum and the accurate mass obtained for the protonated molecule matched those expected for this compound. ${ }^{32-34}$ The chromatographic peak 25 (Figure 2) exhibited nearly identical accurate masses and fragmentation patterns to those obtained for pinostrobin. However, this peak presented an UV spectrum very different from that of pinostrobin, showing the highest 
absorbance above $340 \mathrm{~nm}$, typical of chalcones.$^{35}$ It is know that isomerisation of 2'-hydroxychalcones to the corresponding flavanones occurs in the gas phase, leading to nearly identical mass spectra for these two isomeric forms, ${ }^{36}$ thus, this peak could be assigned to the ringopened, isomeric form of pinostrobin: 2',6'-dihydroxy4'-methoxychalcone. Similarly, peak 19 (Figure 2) also presented an UV spectrum characteristic of chalcones. Comparison of its protonated molecule measured accurate mass with that obtained for peak 25 suggested the absence of a methyl group in the peak 19 compound as compared to 2',6'-dihydroxy-4'-methoxychalcone (peak 25), thus suggesting the corresponding 2',4',6'-trihydroxychalcone for this peak. This could be confirmed by the presence of $\mathrm{m} / \mathrm{z} 153$ in its product ion spectrum, which is the diagnostic ion for a dihydroxy $\mathrm{A}$ ring in flavonoids. ${ }^{32-34}$ Conversely, in product ion spectra of pinostrobin (peak 26) and 2',6'-dihydroxy-4'-methoxychalcone (peak 25), $\mathrm{m} / \mathrm{z} 153$ was absent and the A ring with a hydroxyl and a methoxyl group was confirmed by the presence of the $\mathrm{m} / \mathrm{z}$ 167 fragment.

By comparison of retention times (co-elution), UV and product ion spectra with an authentic standard, peak 22 (Figure 2) was assigned to 3-O-acetylpinobanksin. Peak 27 (Figure 2) produced an UV spectrum characteristic of a flavanone or dihydroflavonol, and its measured accurate mass indicates the molecular formula $\mathrm{C}_{18} \mathrm{H}_{17} \mathrm{O}_{6}$ for the protonated molecule, with no other reasonable molecular formula considering a $15 \mathrm{ppm}$ error interval. This suggests a methyl group in addition to the 3-O-acetylpinobanksin chemical structure (protonated molecule: $\mathrm{C}_{17} \mathrm{H}_{15} \mathrm{O}_{6}$ ). Furthermore, the product ion spectrum obtained for the precursor ion $\mathrm{m} / \mathrm{z}, 329$ (base peak of chromatographic peak 27) exhibited exactly the same fragmentation pattern observed for 3-O-acetylpinobanksin, with an increase of 14 a.m.u. for each product ion. Finally, the presence of the additional methyl group on the A ring could be confirmed by the presence of $m / z 167$ in the product ion spectrum, which is diagnostic for an A ring possessing a hydroxyl and a methoxyl group, as discussed above. ${ }^{32-34}$ Thus, peak 27 was putatively assigned to 3-O-acetylalpinone.

Peaks 14, 16 and 20 (Figure 2) were attributed to the goyazensolide type STL centratherin, 4,5-dihydro-15desoxygoyazensolide and 4,5-dihydroxychnopholide, respectively. Their identification was based primarily on the comparison of retention times (co-elution) of pure samples previously isolated from $L$. ericoides. ${ }^{7}$ Accurate masses obtained are in agreement with the calculated exact masses of the protonated forms of these compounds.

Chromatographic peaks corresponding to eremantholide type STL were identified basically by comparison of their retention times (co-elution) with standards. In this way, peaks 12, 13, 17, 18 and 23 (Figure 2) were attributed, respectively, to the compounds 15 -hydroxyeremantholide $\mathrm{C}$, 15-hydroxy-16 $\alpha$-(1'-methylprop-1'Z-enyl)-eremantholide, 4,5-dihydroeremantholide C, 4,5-dihydro-16 $\alpha$-(1'methylprop-1'-Z-enyl)-eremantholide and 16 $\alpha$-(1'methylprop-1'-Z-enyl)-eremantholide. Moreover, these assigned identities were confirmed by comparison of their product ion spectra with spectra obtained for authentic samples of those compounds, since no fragmentation patterns for this class of compound are described in the literature. All the data obtained for peak 21 (Figure 2) were nearly identical to those obtained for peak 18 [4,5-dihydro$16 \alpha$-(1'-methylprop-1'-Z-enyl)-eremantholide], including the product ion spectra. This strongly suggests that both compounds (peaks 18 and 21) possess the same basic chemical structure, differing in the side chain (the 1'-methylprop-1'-enyl group) configuration. Thus, peak 21 was putatively assigned to the substance 4,5-dihydro$16 \alpha$-(1'-methylprop-1'-E-enyl)-eremantholide, i.e., the $E$-isomer of the compound attributed to peak 18 .

For peak 15 (Figure 2) only the molecular formula could be determined by its accurate mass measurement. Its UV and product ion spectra exhibited patterns very similar to the other STL, strongly suggesting a STL with an eremantholide moiety, because of the first loss of 18 a.m.u., which was observed in all the eremantholide product ion spectra. Finally, for peak 24 (Figure 2) only the molecular formula could be obtained by the measured accurate mass of the base peak observed in the TIC-MS chromatogram, and no product ion spectra could be achieved.

In this manner, the HPLC-DAD-MS/MS analyses and comparison whit authentic samples allowed the identification of chlorogenic acids, STL and flavonoids in the L. ericoides extracts (Figure 1). Although the chemical structure of some peaks could not be fully determined, almost all of them could be assigned to one of the major classes of secondary metabolites occurring in this species, i.e., STL, chlorogenic acids, flavonoid aglicones or $C$-glycosylflavonoids, which is sufficient for the purpose of this study.

In order to check the stability of the secondary metabolite constitution after a long period of storage, samples analysed just after collection by Gobbo-Neto and Lopes ${ }^{5}$ were recently re-analysed (now, after a seven year storage period) employing the same HPLC-DAD method employed for the previous analyses ${ }^{5}$ and the largest variations detected were below the inter- and intra-assay coefficients of variation of that analytical method, leading to the conclusion that, virtually no qualitative or quantitative alteration of the secondary metabolite concentrations occured during storage. 
It should be noted that HPLC-DAD-MS analyses were carried out for the five plants sampled from each population, and it was found that all the individuals from one given population presented nearly identical profiles, including peak intensities (the peak area sum of each of the secondary metabolite classes obtained for each plant are available in Table S2 as Supplementary Information online). This applies to all the populations studied, and supports the use of a pool of plants from each population in the bioassays.

Figure 2 clearly shows that secondary chemistry divergences occur between specimens from different localities, as was also observed for biological activities. The most important point noted in the HPLC-DAD-MS experiments is that the specimens from Ibiraci exhibited the highest number of peaks (i.e., of secondary metabolites) than the other specimens. Figure 2 compares TIC MS chromatograms for the three more diverse situations found for the secondary metabolite chemistry of $L$. ericoides leaves: specimens from Ibiraci, Capitólio and São João Batista do Glória. With regard to secondary metabolites, all other specimens showed chromatographic profiles intermediate between the Capitólio and São João Batista do Glória specimens.

In fact, all specimens, except those from Ibiraci, exhibit very similar TIC MS fingerprints when compared to each other, especially with regard to the absence of STL (peaks 12 to 18, 20, 21 and 23 in Figure 2; see also Table S2 at Supplementary Information online). Comparison between the total peak areas of each class of secondary metabolite obtained for each plant shows that plants from Ibiraci are different from all other plants due to the presence of STL (Ibiraci population STL peak areas: $6.3 \pm 0.3$, other populations: $0 \pm 0 ; \mathrm{F}=2.44, \mathrm{P}<3.2310^{-37}$ ). Thus, the large difference in the cytotoxic assays between the Ibiraci and the other specimens (Table 1) might be explained by the presence of high amounts of STL, known to posses such bioactivity, ${ }^{9-11}$ exclusively in the Ibiraci extracts.

STL in Asteraceae are mainly sequestered in glandular trichomes. ${ }^{31,37}$ To exclude the possibility that the observed difference in STL presence is related to a differential capacity of developing glandular trichomes, leaves of all the analysed plants were examined under a dissecting microscope. Capitate glandular trichomes were present in similar amounts and sizes in leaves of all analysed plants.

The differences in antioxidant activity observed between samples (Table 1) might be due to differences in the amounts of the di- $C$-glucosylflavones vicenin- 2 and 6,8-di- $C$ - $\beta$-glucosyl-chrysin (peaks 2 and 3; Figure 2) and chlorogenic acids (peaks 1 and 4 to 11; Figure 2), all of which are known to possess strong antioxidant properties. ${ }^{3,28,29}$ Thus, the higher antioxidant activity exhibited by the Ibiraci sample might be related to its higher contents of both antioxidant di- $C$-glucosylflavones and chlorogenic acids. Likewise, the lowest antioxidant activity recorded for the São João Batista do Glória sample could be explained by its relatively low content of both di- $C$-glucosylflavones and chlorogenic acids. The Capitólio sample, which is intermediate in its antioxidant activity, presented a lower content of antioxidant di- $C$ glucosylflavones compared to the Ibiraci sample, but had the highest amount of chlorogenic acids among the plants studied, as can be seen in Figure 2 (see also Table S2 of Supplementary Information online).

\section{Experimental}

\section{General experimental procedures}

Methanol $(\mathrm{MeOH})$, acetonitrile $(\mathrm{MeCN})$ and acetic acid were HPLC grade and obtained from Aldrich or J. T. Baker. De-ionised water (Milli-Q) was used throughout the study. Solutions of different $\mathrm{pH}$ values were achieved by addition of formic acid $0.1 \mathrm{~mol} \mathrm{~L}^{-1}$, unless stated otherwise. The $\mathrm{pH}$ measurements were carried out on a Model $3015 \mathrm{pH}$ meter from Jenway Dunmow (Essex, UK).

\section{Plant material}

Lychnophora ericoides Mart. (Asteraceae, Vernonieae) specimens from Minas Gerais State were collected in March 1998, by Leonardo Gobbo Neto and Norberto P. Lopes at: Ibiraci (NPL284; S 20²0'046', W 04708'229'; 1090 m altitude), Delfinópolis (NPL123; S 20²0'550", W 04647'638"; $870 \mathrm{~m}$ altitude), Capitólio (NPL225; S 2042'107', W 046¹7'336"; 1090 m altitude), São João Batista do Glória (NPL221; S 20³7'540", W 046¹9'391"; $900 \mathrm{~m}$ altitude) and São José da Barra (NPL227; S 20³8'316”, W 046¹5’318”; 1010 m altitude), and identified by Prof. Dr. João Semir (Universidade Estadual de Campinas-UNICAMP, São Paulo State, Brazil), where voucher specimens were deposited under the codes NPL284, NPL123, NPL225, NPL221 and NPL227. Specimens from Goiás State were collected and identified by Roberto F. Vieira (Embrapa/Brasilia-Federal District, Brazil) in March 1998, at Pirenópolis (R.F.Vieira \& J.Dias 2251, S 15 48'18', W 48 48'21'; 1187 m altitude) and Cocalzinho (R.F.Vieira \& J.Dias 2252, S 1544'16", W $48^{\circ} 49^{\prime} 46^{\prime \prime}$; 1143 m altitude); voucher specimens for the latter were deposited at Embrapa/Brasília under the codes R.F.Vieira \& J.Dias 2251 and R.F.Vieira \& J.Dias 2252.

Five plants for each population were individually sampled. For this, a branch containing only intact leaves 
was chosen and all its leaves were collected to minimize possible ontogenetic variation between leaves in the same plant specimen, i.e., leaves of all ages were collected in each plant. After collection, plant material was brought to the laboratory and then dried, as soon as possible, at $40{ }^{\circ} \mathrm{C}$ under forced ventilation for $48 \mathrm{~h}$, and stored in a freezer prior to analysis. Each plant was individually analysed by HPLC-DAD-MS to confirm the similarities in their secondary metabolite profiles. For HPLC-ECD and cytotoxic and antioxidant activity assays, pools consisting of equivalent parts (weight) of powdered leaves of the five plants of each population were used.

\section{Plant extracts}

Prior to analyses, $40 \mathrm{mg}$ of powdered leaves were extracted with $3.0 \mathrm{~mL}$ of $\mathrm{MeOH}-\mathrm{H}_{2} \mathrm{O}(9: 1)$ for $10 \mathrm{~min}$ in an ultrasonic bath. Extracts were then submitted to liquidliquid extraction with an equal volume of hexane and filtered through a $0.45 \mu \mathrm{m}$ cellulose acetate membrane. For HPLC-DAD-MS/MS and HPLC-ECD analysis, $20 \mu \mathrm{L}$ of the obtained extract were injected into the column system. For bioassays, extracts were dried and used as stated below.

\section{Cytotoxic activity assay}

The activity of $L$. ericoides extracts on cellular growth was evaluated against three tumor cell lines (National Cancer Institute, Bethesda, MD, USA): HCT-8 (human colon), SF-268 (human nervous system) and MDAMB-435 (human breast). All cell lines were maintained in RPMI 1640 supplemented with $10 \%$ fetal bovine serum, $2 \mathrm{mmol} \mathrm{L}^{-1}$ glutamine, $100 \mathrm{U} \mathrm{mL}^{-1}$ penicillin, $100 \mu \mathrm{g} \mathrm{mL}^{-1}$ streptomycin at $37{ }^{\circ} \mathrm{C}$ with $5 \% \mathrm{CO}_{2}$. Tumor cell growth was quantified by the ability of living cells to reduce the yellow dye 3-(4,5-dimethyl-2-thiazolyl)-2,5-diphenyl-2Htetrazolium bromide (MTT) to the purple formazan product. For experiments, cells were plated in 96-well plates ( $10^{5}$ cells/well in $100 \mu \mathrm{L}$ of medium). After $24 \mathrm{~h}$, the extracts $\left(100 \mu \mathrm{g} \mathrm{mL}^{-1}\right)$ dissolved in DMSO (1\%) were added to each well and incubated for 3 days (72 h). Control groups received the same amount of DMSO. Doxorubicin was used as positive control. The plates were then centrifuged and the medium replaced by fresh medium $(200 \mu \mathrm{L})$ containing $0.5 \mathrm{mg} \mathrm{mL}^{-1} \mathrm{MTT}$. Three hours later, the MTT formazan product was dissolved in $150 \mu \mathrm{L}$ DMSO and the absorbance measured using a multiplate reader (Spectra Count, Packard, Ontario, Canada). Drug effect was quantified as the percentage of control absorbance of reduced dye at $550 \mathrm{~nm}$.
Antioxidant activity by the DPPH radical scavenging system

Radical scavenging activity was spectrophotometrically evaluated in an ELX808 IU Ultra Microplate Reader (BioTek Instruments, Inc) by monitoring the disappearance of 1,1-diphenyl-2-picrylhydrazyl (DPPH) at $517 \mathrm{~nm}$, as previously described. ${ }^{38}$ In this study, increasing concentrations of each extract soln., prepared in $\mathrm{MeOH}-\mathrm{H}_{2} \mathrm{O}$ (1:1), were mixed with $10 \mu \mathrm{L}$ of DPPH soln. $\left(1 \mathrm{mmol} \mathrm{L}^{-1}\right)$ in a 96-well plate and completed to $100 \mu \mathrm{L}$ with methanol. The plate was incubated for $15 \mathrm{~min}$ in the dark at room temperature and the experiments were performed in triplicate. Rutin was used as a positive reference and the radical scavenging activity, expressed as the percentage of inhibition, was calculated according to the formula: $\%$ Inhibition $=\left[\left(\mathrm{A}_{\text {control }}-\mathrm{A}_{\text {sample }}\right) / \mathrm{A}_{\text {control }}\right] \times 100$, where $\mathrm{A}_{\text {control }}$ is the absorbance of the DPPH soln. without the sample and $A_{\text {sample }}$ is the absorbance of the extract tested. ${ }^{38} \mathrm{EC}_{30}$ values were calculated as the minimum concentration of each sample required to inhibit $30 \%$ of the DPPH radical. Data were statistically analysed with one-way ANOVA and differences were considered statistically significant when probability levels were less than 0.05 .

HPLC-DAD-MS, HPLC-DAD-MS/MS and HPLC-ECD analysis

HPLC-DAD-MS analyses were performed on a Shimadzu LC-20A HPLC apparatus with a Diode Array Detector (CBM20A, Shimadzu) using a Shimpack ODS column ( $5 \mu \mathrm{m}, 4.6 / 250 \mathrm{~mm}$; Shimadzu), coupled to an UltrOTOFq (Bruker Daltonics) ESI-qTOF mass spectrometer. The column eluent was split at a ratio of 3:1, the larger flow going to the DAD detector and the lower flow to the mass spectrometer. The following elution gradient was employed with a flow rate of $1.5 \mathrm{~mL} \mathrm{~min}^{-1}$ : solvent $\mathrm{A}=$ aq. acetic acid $2 \%(\mathrm{v} / \mathrm{v})$; solvent $\mathrm{B}=\mathrm{MeCN}-\mathrm{MeOH}-$ HOAc (85:13:2); elution profile: 0 to 50 min: 15 to $60 \%$ B (linear gradient), 50 to $55 \mathrm{~min}$ : 60 to $100 \%$ B (linear gradient). UV-DAD detector was set to record between 210 and $450 \mathrm{~nm}$, and UV chromatograms were recorded at 275 and $325 \mathrm{~nm}$. MS TIC chromatograms were recorded between $\mathrm{m} / \mathrm{z}, 50$ and 900 in the positive mode and the mass spectrometer parameters were maintained the same in all analyses: 1000 scans per second; spectrum interval: $2 \mathrm{~s}$; drying gas flow: $5.01 \mathrm{~min}^{-1}$; drying gas temperature: $180^{\circ} \mathrm{C}$; nebulising gas pressure: 4 bar. After each HPLCDAD-MS run, $\mathrm{m} / \mathrm{z}$ and retention time data obtained for each chromatographic peak were used to determine the HPLC-DAD-MS/MS fragmentation parameters, i.e., for 
online MS/MS, the retention times and $\mathrm{m} / \mathrm{z}$ of the ion to be fragmented in the collision cell were used combined as the input for the mass spectrometer software. Collision-induced dissociation (CID) fragmentation was performed using $\mathrm{N}_{2}$ as collision gas on each isolated, protonated molecule using collision energies between 10 and $20 \mathrm{eV}$.

HPLC-ECD was performed in a similar HPLC and UV detector system, using the same method as described above. This system was coupled to a Model Coulochem III electrochemical detector (ECD) (ESA Inc., Chelmsford, MA) and consisted of a guard cell (Model 5021) and an analytical cell (Model 5010) with two porous graphite working electrodes, palladium reference electrodes and platinum counter electrodes. The ECD detector was operated in the DC-mode with a guard channel potential of $+850 \mathrm{mV}$ to improve the baseline signal by oxidizing interfering compounds possibly present in the mobile phase. Different chromatograms were obtained by varying the potential of the first cell $(+100$ to $+900 \mathrm{mV}$, in $50 \mathrm{mV}$ increments). The cumulative peak area was calculated by summing the peak areas of chromatograms obtained at 100,250 and $500 \mathrm{mV}$.

For comparison between samples, the peak areas at $275 \mathrm{~nm}$ related to each secondary metabolite class (i.e., chlorogenic acids, STL, $C$-glycosylflavones and flavonoid aglycones) were summed for each plant analysed. The obtained total areas of each secondary metabolite group found for each plant were used for comparison between populations and are available in Table S2 as Supplementary Information online. Data were statistically analysed with one-way ANOVA to show the differences between populations regarding each class of secondary metabolite.

It has already been shown elsewhere that leaves of $L$. ericoides stored for up to two years presented no significant qualitative or quantitative variation in their secondary metabolite composition. ${ }^{5}$ In order to check the stability of the secondary metabolite constitution after longer storage periods, the same samples analysed after two years bt Gobbo-Neto and Lopes (2008) ${ }^{5}$ were recently re-analysed (after a total of seven years of storage) employing the same validated HPLC-DAD method. ${ }^{5}$

\section{Identification of compounds}

Compound identification relied primarily on possible molecular formulae calculated from measured accurate masses and UV spectra obtained from the HPLC-DAD-MS analysis, and comparison of these data with the secondary chemistry previously reported for $L$. ericoides. ${ }^{3,5-7}$ Co-injection of authentic standards was also used for peak identity confirmation, when standards were available. HPLC-DAD-MS/MS was subsequently carried out for the structure elucidations of some compounds and/or to support the peak assignments. Fundamental information for the structure elucidation was obtained from previous reports that identified the key fragments of caffeoylquinic acid derivatives $\left(\mathrm{C}_{6} \mathrm{C}_{3}\right.$ moiety elimination) and of flavonoids (C-ring fragmentation pattern), in the positive mode of ionisation. The fragmentation patterns of caffeoylquinic acids, ${ }^{30}$ flavonoids ${ }^{32-34}$ and chalcones ${ }^{36}$ were compared with those reported elsewhere, and fragmentation patterns of STL were compared with spectra obtained by us for authentic samples previously isolated by our group.

Authentic standards used were obtained from the following sources: 5-O-E-caffeoylquinic acid was bought from Acros (Belgium); pinostrobin, vicenin-2, 6,8-di$C$ - $\beta$-glucosylchrysin, 15-hydroxy-16 $\alpha$-(1'-methylprop1 '-Z-enyl)-eremantholide, 4,5-dihydroeremantholide C, 4,5-dihydro-16 $\alpha$-(1'-methylprop-1'Z-enyl)-eremantholide, $16 \alpha$-(1'-methylprop-1'-Z-enyl)-eremantholide, centratherin, 4,5-dihydro-15-desoxygoyazensolide, 4,5-dihydrolychnopholide, 3,5-, 4,5-, 3,4-di-O-Ecaffeoylquinic acids and 3,4,5-tri- $O$ - $E$-caffeoylquinic acid were previously isolated from $L$. ericoides ${ }^{3,4,6,7}$ 3-O-acetylpinobanksin was previously isolated from L. staavioides ${ }^{39}$ and 15 -hydroxyeremantholide $\mathrm{C}$ was previously isolated from $L$. rupestris. ${ }^{40}$

\section{Conclusions}

Application of HPLC-DAD-MS/MS analyses allowed the characterisation of eco-geographical variations in the secondary defensive metabolite profiles of $L$. ericoides leaf extracts, demonstrating the efficiency of these hyphenated techniques for chemo-ecological studies. Moreover, HPLCECD furnished additional information on antioxidant activity, and was in agreement with data from the DPPH assay.

The amplified defensive secondary chemistry profile and the differentiated bioactivities exhibited by the plants collected at a frontier between two types of forest (the Ibiraci population) furnish important additional support for the hypothesis that plants occurring at the border between different types of forest might be stimulated to amplify the production and storage of defensive secondary metabolites.

\section{Supplementary Information}

Supplementary data are available free of charge at http://jbcs.sbq.org.br, as PDF file. 


\section{Acknowledgments}

This research was supported by the Brazilian foundations CNPq, FAPESP, CAPES, CNPq/Milênio and FINEP. The authors would like to thank Prof. Dr. João Semir (Instituto de Biologia, Universidade Estadual de Campinas-UNICAMP, Brazil) for the plant identification, Dr. Adrian M. Pohlit for the english revision and Prof. Dr. Fernando B. da Costa, Prof. Dr. Rodrigo A. S. Pereira, Paula C.P. Bueno, José C. Tomaz and Herbert J. L. Mendonça for technical support and facilities. The authors also thank IBAMA for license number 029/2006.

\section{References}

1. Semir, J.; Ph.D. Thesis, Universidade Estadual de Campinas, Campinas, 1991.

2. Robinson, H.; Generic and Subtribal Classification of American Vernonieae, Smithsonian Institute Press: Washington D.C., 1999.

3. Gobbo-Neto, L.; Santos, M. D.; Kanashiro, A.; Almeida, M. C.; Lucisano-Valim, Y. M.; Lopes, J. L. C.; Souza, G. E. P.; Lopes, N. P.; Planta Med. 2005, 71, 3.

4. dos Santos, M. D.; Gobbo-Neto, L.; Albarella, L.; de Souza, G. E. P.; Lopes, N. P.; J. Ethnopharmacol. 2005, 96, 545.

5. Gobbo-Neto, L.; Lopes, N. P.; J. Agric. Food Chem. 2008, 56, 1193.

6. Gobbo-Neto, L.; dos Santos, M. D.; Albarella, L.; Zollo, F.; Pizza, C.; Lopes, N. P.; Biochem. Syst. Ecol. 2008, 36, 473.

7. Sakamoto, H. T.; Flausino, D.; Castellano, E. E.; Stark, C. B. W.; Gates, P. J.; Lopes, N. P.; J. Nat. Prod. 2003, 66, 693.

8. Borsato, M. L. C.; Grael, C. F. F.; Souza, G. E. P.; Lopes, N. P.; Phytochemistry 2000, 55, 809.

9. Rodriguez, E.; Towers, G. H. N.; Mitchell, J. C.; Phytochemistry 1976, 15, 1573.

10. Picman, A. K.; Biochem. Syst. Ecol. 1986, 14, 255.

11. Schmidt, T. J.; Curr. Org. Chem. 1999, 3, 577.

12. Rungeler, P.; Castro, V.; Mora, G.; Goren, N.; Vichnewski, W.; Pahl, H. L.; Merfort, I.; Schmidt, T. J.; Bioorg. Med. Chem. 1999, 7, 2343.

13. Rees, S. B.; Harborne, J. B.; Phytochemistry 1985, 24, 2225.

14. Passreiter, C. M.; Isman, M. B.; Biochem. Syst. Ecol. 1997, 25 , 371.

15. Cis, J.; Nowak, G.; Kisiel, W.; Biochem. Syst. Ecol. 2006, 34, 862.

16. Macias, F. A.; Fernandez, A.; Varela, R. M.; Molinillo, J. M. G.; Torres, A.; Alves, P.; J. Nat. Prod. 2006, 69, 795.

17. Waterman, P. G.; Mole, S. In Analysis of Phenolic Plant Metabolites; Waterman, P. G.; Mole, S., eds. Blackwell Scientific Publications: Oxford, UK, 1994.
18. Gobbo-Neto, L.; Lopes, N. P.; Quim. Nova 2007, 30, 374.

19. Gottlieb, O. R.; Phytochemistry 1990, 29, 1715.

20. Gottlieb, O. R.; Borin, M. R. M. B.; Mem. Inst. Oswaldo Cruz. 2000, 95, 115.

21. Gottlieb, O. R.; Kaplan, M. A. C.; Borin, M. R. M. B.; Biodiversidade: Um Enfoque Químico-Biológico, Editora UFRJ: Rio de Janeiro, Brazil, 1996.

22. Crotti, A. E. M.; Carollo, C. A.; Gobbo-Neto, L.; Santos, M. D.; Gates, P. J.; Lopes, N. P. In Modern Biotechnology in Medicinal Chemistry and Industry; TAFT, C. A., ed., Research Signpost: Kerala, India, 2006.

23. Abreu, F. C.; Ferraz, P. A. L.; Goulart, M. O. F.; J. Braz. Chem. Soc. 2002, 13, 19.

24. Castro-Gamboa, I.; Cardoso, C. L.; Silva, D. H. S.; Cavalheiro, A. J.; Furlan, M.; Bolzani, V. S.; J. Braz. Chem. Soc. 2003, 14, 771.

25. Aaby, K.; Hvattum, E.; Skrede, G.; J. Agric. Food Chem. 2004, 52,4595 .

26. Guo, C. J.; Cao, G. H.; Sofic, E.; Prior, R. L.; J. Agric. Food Chem. 1997, 45, 1787.

27. Cuyckens, F.; Claeys, M.; J. Mass Spectrom. 2005, 40, 364.

28. Maruta, Y.; Kawabata, J.; Niki, R.; J. Agric. Food Chem. 1995, 43, 2592.

29. Chen, J. H.; Ho, C. T.; J. Agric. Food Chem. 1997, 45, 2374.

30. Miketova, P.; Schram, K. H.; Whitney, J.; Kearns, E. H.; Timmermann, B. N.; J. Mass Spectrom. 1999, 34, 1240.

31. Gobbo-Neto, L.; Gates, P. J.; Lopes, N. P.; Rapid Commun. Mass Spectrom. 2008, 22, 3802.

32. Ma, Y. L.; Li, Q. M.; VandenHeuvel, H.; Claeys, M.; Rapid Commun. Mass Spectrom. 1997, 11, 1357.

33. Cuyckens, F.; Claeys, M.; J. Mass Spectrom. 2004, 39, 1.

34. Tsimogiannis, D.; Samiotaki, M.; Panayotou, G.; Oreopoulou, V.; Molecules 2007, 12, 593.

35. Markham, K. R.; Techniques of Flavonoid Identification, Academic Press: London, UK, 1982.

36. Zhang, J. M.; Brodbelt, J. S.; J. Mass Spectrom. 2003, 38, 555.

37. Spring, O.; Bienert, U.; J. Plant Physiol. 1987, 130, 441.

38. Yokozawa, T.; Chen, C. P.; Dong, E.; Tanaka, T.; Nonaka, G. I.; Nishioka, I.; Biochem. Pharmacol. 1998, 56, 213.

39. Takeara, R.; Albuquerque, S.; Lopes, N. P.; Lopes, J. L. C.; Phytomedicine 2003, 10, 490.

40. Cunha, W. R.; Lopes, J. L. C.; Vichnewski, W.; Diaz, J. G.; Herz, W.; Phytochemistry 1995, 39, 387.

Received: December 14, 2008 Web Release Date: February 8, 2010

FAPESP helped in meeting the publication costs of this article. 


\title{
Differential Metabolic and Biological Profiles of Lychnophora ericoides Mart. (Asteraceae) from Different Localities in the Brazilian "campos rupestres"
}

\author{
Leonardo Gobbo-Neto, ${ }^{a}$ Thais Guaratini, ${ }^{b}$ Cláudia Pessoa, ${ }^{c}$ Manoel O. de Moraes, ${ }^{c}$ \\ Letícia V. Costa-Lotufo, ${ }^{c}$ Roberto F. Vieira, ${ }^{d}$ Pio Colepicolo ${ }^{b}$ and Norberto P. Lopes ${ }^{*, a}$
}

${ }^{a}$ Departamento de Física e Química, Faculdade de Ciências Farmacêuticas de Ribeirão Preto, Universidade de São Paulo, 14040-903 Ribeirão Preto-SP, Brazil

${ }^{b}$ Instituto de Química, Universidade de São Paulo, 05508-900 São Paulo-SP, Brazil

${ }^{c}$ Departamento de Fisiologia e Farmacologia, Faculdade de Medicina, Universidade Federal do Ceará, 60431-970 Fortaleza-CE, Brazil

${ }^{d}$ Embrapa Recursos Genéticos e Biotecnologia, Parque Estação Biológica, 70770-900 Brasília-DF, Brazil

Table S1. Identification of chromatographic peaks obtained for Lychnophora ericoides leaf extracts and data taken from HPLC-DAD-MS and HPLCDAD-MS/MS analyses

\begin{tabular}{|c|c|c|c|c|c|}
\hline Peak & $\begin{array}{l}\mathrm{t} / \\
\min \end{array}$ & Secondary metabolites & Observed MS TIC ions $(\mathrm{m} / \mathrm{z})$ & MS/MS $(m / z)$ & $\mathrm{UV}_{\max } / \mathrm{nm}$ \\
\hline 1 & 3.7 & 5-O-E-caffeoylquinic acid & $\begin{array}{l}{[\mathrm{M}+\mathrm{H}]^{+} 355.1035^{\text {b.p. }}} \\
{[\mathrm{M}+\mathrm{Na}]^{+} 377} \\
{[(\mathrm{M}+\mathrm{H})-\mathrm{QA}]^{+} 163}\end{array}$ & $355 \rightarrow 163^{\text {b.p. }}$ & 299,325 \\
\hline 2 & 4.7 & $\begin{array}{l}\text { 6,8-di- } C \text { - } \beta \text {-glucopyranosylapigenin } \\
\text { (vicenin- } 2 \text { ) }\end{array}$ & $\begin{array}{l}{[\mathrm{M}+\mathrm{H}]^{+} 595.1655^{\text {b.p. }}} \\
{\left[(\mathrm{M}+\mathrm{H})-\mathrm{H}_{2} \mathrm{O}\right]^{+} 577}\end{array}$ & $\begin{array}{l}595 \rightarrow 577,559,541,529,523,511 \\
481,475,457^{\text {b.p. }}, 427,409\end{array}$ & 271,333 \\
\hline 3 & 7.8 & 6,8-di- $C$ - $\beta$-glucopyranosylchrysin & $\begin{array}{l}{[\mathrm{M}+\mathrm{H}]^{+} 579.1708^{\text {b.p. }}} \\
{\left[(\mathrm{M}+\mathrm{H})-\mathrm{H}_{2} \mathrm{O}\right]^{+} 561}\end{array}$ & $\begin{array}{l}579 \rightarrow 561,543,525,513,507,495 \\
465,459,441^{\text {b.p. }}, 411,393\end{array}$ & 272,316 \\
\hline 4 & 11.3 & 3,4-di-O-E-caffeoylquinic acid & $\begin{array}{l}{[\mathrm{M}+\mathrm{H}]^{+} 517.1355} \\
{\left[(\mathrm{M}+\mathrm{H})-\mathrm{H}_{2} \mathrm{O}\right]^{+} 499^{\text {b.p. }}} \\
{[\mathrm{M}+\mathrm{Na}]^{+} 539}\end{array}$ & $499 \rightarrow 319^{\text {p.b. }}, 163$ & 299,324 \\
\hline 5 & 12.1 & 3,5-di-O-E-caffeoylquinic acid & $\begin{array}{l}{[\mathrm{M}+\mathrm{H}]^{+} 517.1354} \\
{\left[(\mathrm{M}+\mathrm{H})-\mathrm{H}_{2} \mathrm{O}\right]^{+} 499^{\text {b.p. }}} \\
{[\mathrm{M}+\mathrm{Na}]^{+} 539}\end{array}$ & $499 \rightarrow 319^{\text {p.b. }}, 163$ & 300,325 \\
\hline 6 & 14.1 & 4,5-di-O-E-caffeoylquinic acid & $\begin{array}{l}{[\mathrm{M}+\mathrm{H}]^{+} 517.1357} \\
{\left[(\mathrm{M}+\mathrm{H})-\mathrm{H}_{2} \mathrm{O}\right]^{+} 499^{\text {b.p. }}} \\
{[\mathrm{M}+\mathrm{Na}]^{+} 539}\end{array}$ & $499 \rightarrow 319^{\text {p.b. }}, 163$ & 300,326 \\
\hline 7 & 15.0 & caffeoylferuloylquinic acid ${ }^{\mathrm{a}}$ & $\begin{array}{l}{[\mathrm{M}+\mathrm{H}]^{+} 531.1510} \\
{\left[(\mathrm{M}+\mathrm{H})-\mathrm{H}_{2} \mathrm{O}\right]^{+} 513^{\text {b.p. }}} \\
{[\mathrm{M}+\mathrm{Na}]^{+} 553}\end{array}$ & $513 \rightarrow 333,319,177^{\text {b.p. }}, 163$ & 300,324 \\
\hline 8 & 16.3 & caffeoylferuloylquinic acid ${ }^{a}$ & $\begin{array}{l}{[\mathrm{M}+\mathrm{H}]^{+} 531.1512} \\
{\left[(\mathrm{M}+\mathrm{H})-\mathrm{H}_{2} \mathrm{O}\right]^{+} 513^{\text {b.p. }}} \\
{[\mathrm{M}+\mathrm{Na}]^{+} 553}\end{array}$ & $513 \rightarrow 333,319,177^{\text {b.p. }}, 163$ & 299,324 \\
\hline 9 & 18.0 & caffeoylferuloylquinic acid ${ }^{\mathrm{a}}$ & $\begin{array}{l}{[\mathrm{M}+\mathrm{H}]^{+} 531.1508} \\
{\left[(\mathrm{M}+\mathrm{H})-\mathrm{H}_{2} \mathrm{O}\right]^{+} 513^{\text {b.p. }}} \\
{[\mathrm{M}+\mathrm{Na}]^{+} 553}\end{array}$ & $513 \rightarrow 333,319,177^{\text {b.p. }}, 163$ & 300,325 \\
\hline
\end{tabular}


Table S1. continuation

\begin{tabular}{|c|c|c|c|c|c|}
\hline Peak & $\begin{array}{l}\mathrm{t} / \\
\min \end{array}$ & Secondary metabolites & Observed MS TIC ions $(\mathrm{m} / \mathrm{z})$ & MS/MS $(m / z)$ & $\mathrm{UV}_{\max } / \mathrm{nm}$ \\
\hline 10 & 18.9 & caffeoylferuloylquinic acid ${ }^{\mathrm{a}}$ & $\begin{array}{l}{[\mathrm{M}+\mathrm{H}]^{+} 531.1513} \\
{\left[(\mathrm{M}+\mathrm{H})-\mathrm{H}_{2} \mathrm{O}\right]^{+} 513^{\text {b.p. }}} \\
{[\mathrm{M}+\mathrm{Na}]^{+} 553}\end{array}$ & $513 \rightarrow 333,319,177^{\text {b.p. }}, 163$ & 299,325 \\
\hline 11 & 21.3 & 3,4,5-tri- $O$ - $E$-caffeoylquinic acid & $\begin{array}{l}{[\mathrm{M}+\mathrm{H}]^{+} 679.1673} \\
{\left[(\mathrm{M}+\mathrm{H})-\mathrm{H}_{2} \mathrm{O}\right]^{+} 661} \\
\left.\left[(\mathrm{M}+\mathrm{H})-\mathrm{CAF}-\mathrm{H}_{2} \mathrm{O}\right)\right]^{+} 499^{\text {b.p. }} \\
{[\mathrm{M}+\mathrm{Na}]^{+} 701}\end{array}$ & $513 \rightarrow 661,499,163^{\text {b.p. }}$ & 299,326 \\
\hline 12 & 22.0 & 15-hydroxyeremantholide $\mathrm{C}$ & $\begin{array}{l}{[\mathrm{M}+\mathrm{H}]^{+} 363.1449} \\
{\left[(\mathrm{M}+\mathrm{H})-\mathrm{H}_{2} \mathrm{O}\right]^{+} 345^{\text {b.p. }}}\end{array}$ & $\begin{array}{l}363 \rightarrow 345,301 \\
345 \rightarrow 301,283,255^{\text {b.p. }}, 203\end{array}$ & 266 \\
\hline 13 & 26.8 & $\begin{array}{l}\text { 15-hydroxy-16 } \alpha \text {-(1'-methylprop-1'- } \\
\text { Z-enyl)-eremantholide }\end{array}$ & $\begin{array}{l}{[\mathrm{M}+\mathrm{H}]^{+} 377.1612} \\
{\left[(\mathrm{M}+\mathrm{H})-\mathrm{H}_{2} \mathrm{O}\right]^{+} 359^{\text {b.p. }}}\end{array}$ & $\begin{array}{l}377 \rightarrow 359,315 \\
359 \rightarrow 315,297,269,241,213 \\
203^{\text {b.p. }}, 175\end{array}$ & 267 \\
\hline 14 & 27.8 & centratherin & $\begin{array}{l}{[\mathrm{M}+\mathrm{H}]^{+} 375.1452} \\
{[\mathrm{M}+\mathrm{Na}]^{+} 397}\end{array}$ & $\begin{array}{l}375 \rightarrow 275,257,239,229^{\text {b.p. }}, 211, \\
201,183,83\end{array}$ & 268 \\
\hline 15 & 31.1 & $\begin{array}{l}\text { unidentified STL } \\
\mathrm{C}_{19} \mathrm{H}_{24} \mathrm{O}_{6}\end{array}$ & $\begin{array}{l}{[\mathrm{M}+\mathrm{H}]^{+} 349.1660} \\
{\left[(\mathrm{M}+\mathrm{H})-\mathrm{H}_{2} \mathrm{O}\right]^{+} 331^{\text {b.p. }}}\end{array}$ & $\begin{array}{l}349 \rightarrow 331,241,215,189^{\text {b.p. }}, 161 \\
331 \rightarrow 241,229,215,189^{\text {b.p. }}, 161\end{array}$ & 265 \\
\hline 16 & 33.0 & 4,5-dihydro-15-desoxygoyazensolide & $\begin{array}{l}{[\mathrm{M}+\mathrm{H}]^{+} 347.1501} \\
{[\mathrm{M}+\mathrm{Na}]^{+} 369}\end{array}$ & $\begin{array}{l}347 \rightarrow 261,243,233,215^{\text {b.p. }}, 187, \\
159,69\end{array}$ & 265 \\
\hline 17 & 34.2 & 4,5-dihydroeremantholide $\mathrm{C}$ & $\begin{array}{l}{[\mathrm{M}+\mathrm{H}]^{+} 349.1659} \\
{\left[(\mathrm{M}+\mathrm{H})-\mathrm{H}_{2} \mathrm{O}\right]^{+} 331^{\text {b.p. }}}\end{array}$ & $\begin{array}{l}349 \rightarrow 331,189^{\text {b.p. }}, 161 \\
331 \rightarrow 285,257,217,189^{\text {b.p. }}, 161\end{array}$ & 265 \\
\hline 18 & 36.4 & $\begin{array}{l}\text { 4,5-dihydro- } 16 \alpha \text {-(1'-methylprop-1'- } \\
\text { Z-enyl)- eremantholide }\end{array}$ & $\begin{array}{l}{[\mathrm{M}+\mathrm{H}]^{+} 363.1815} \\
{\left[(\mathrm{M}+\mathrm{H})-\mathrm{H}_{2} \mathrm{O}\right]^{+} 345^{\text {b.p. }}}\end{array}$ & $\begin{array}{l}363 \rightarrow 345,203,189^{\text {b.p. }} \\
345 \rightarrow 317,219,203,189^{\text {b.p. }}, 161\end{array}$ & 264 \\
\hline 19 & 38.2 & putative 2',4',6'-trihydroxychalcone & {$[\mathrm{M}+\mathrm{H}]^{+} 257.0809^{\text {b.p. }}$} & $257 \rightarrow 239,215,179,173,153^{\text {b.p. }}$ & 343 \\
\hline 20 & 38.4 & 4,5-dihydrolychnopholide & $\begin{array}{l}{[\mathrm{M}+\mathrm{H}]^{+} 361.1645^{\text {b.p. }}} \\
{[\mathrm{M}+\mathrm{Na}]^{+} 383}\end{array}$ & $\begin{array}{l}361 \rightarrow 261,243,233,215^{\text {b.p. }}, 197, \\
187,169,83\end{array}$ & 264 \\
\hline 21 & 39.3 & $\begin{array}{l}\text { putative } 4,5 \text {-dihydro- } 16 \alpha-(1 \text { '- } \\
\text { methylprop-1'-E-enyl)- eremantholide }\end{array}$ & $\begin{array}{l}{[\mathrm{M}+\mathrm{H}]^{+} 363.1815} \\
{\left[(\mathrm{M}+\mathrm{H})-\mathrm{H}_{2} \mathrm{O}\right]^{+} 345^{\text {b.p. }}}\end{array}$ & $\begin{array}{l}363 \rightarrow 345,203,189^{\text {b.p. }} \\
345 \rightarrow 317,219,203,189^{\text {b.p. }}, 161\end{array}$ & 264 \\
\hline 22 & 40.0 & 3-O-acetylpinobanksin & $\begin{array}{l}{[\mathrm{M}+\mathrm{H}]^{+} 315.0875^{\text {b.p. }}} \\
{\left[(\mathrm{M}+\mathrm{H})-\mathrm{C}_{2} \mathrm{H}_{2} \mathrm{O}\right]^{+} 273}\end{array}$ & \multicolumn{2}{|c|}{$315 \rightarrow 273,255,227^{\text {b.p. }}, 199,181,153291,335 \mathrm{sh}$} \\
\hline 23 & 41.8 & $\begin{array}{l}16 \alpha \text {-(1'-methylprop-1'-Z-enyl)- } \\
\text { eremantholide }\end{array}$ & $\begin{array}{l}{[\mathrm{M}+\mathrm{H}]^{+} 361.1643} \\
{\left[(\mathrm{M}+\mathrm{H})-\mathrm{H}_{2} \mathrm{O}\right]^{+} 343^{\text {b.p. }}}\end{array}$ & $\begin{array}{l}361 \rightarrow 343,215,187^{\text {b.p. }} \\
343 \rightarrow 299,281,269,243,215 \\
187^{\text {b.p. }}, 159\end{array}$ & 267 \\
\hline 24 & 43.7 & $\mathrm{C}_{19} \mathrm{H}_{20} \mathrm{O}_{5}$ & $\begin{array}{l}{[\mathrm{M}+\mathrm{H}]^{+} 329.1379^{\text {b.p. }}} \\
{[\mathrm{M}+\mathrm{Na}]^{+} 351}\end{array}$ & 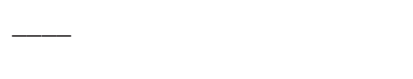 & 276 \\
\hline 25 & 48.2 & 2',6'-dihydroxy-4'-methoxychalcone & $\begin{array}{l}{[\mathrm{M}+\mathrm{H}]^{+} 271.0980^{\text {b.p. }}} \\
{[\mathrm{M}+\mathrm{Na}]^{+} 293}\end{array}$ & $271 \rightarrow 167^{\text {b.p. }}, 131$ & 340 \\
\hline 26 & 51.8 & pinostrobin & $\begin{array}{l}{[\mathrm{M}+\mathrm{H}]^{+} 271.0977^{\text {b.p. }}} \\
{[\mathrm{M}+\mathrm{Na}]^{+} 293}\end{array}$ & $271 \rightarrow 167^{\text {b.p. }}, 131$ & 289,330 sh \\
\hline 27 & 55.1 & putative 3-O-acetylalpinone & $\begin{array}{l}{[\mathrm{M}+\mathrm{H}]^{+} 329.1033^{\text {b.p. }}} \\
{[\mathrm{M}+\mathrm{Na}]^{+} 351}\end{array}$ & \multicolumn{2}{|c|}{$329 \rightarrow 287,269,241,213^{\text {b.p. }}, 195,167286,330$ sh } \\
\hline
\end{tabular}

${ }^{a}$ positional isomers of caffeoylquinic acids which could not be distinguishable from each other. ${ }^{\text {b.p.base }}$ peak (100\% relative abundance). sh $=$ shoulder; $\mathrm{CAF}=$ caffeoyl $\mathrm{QA}=$ quinic acid. 
Table S2. Sum of chromatographic peak areas at $275 \mathrm{~nm}$ obtained from the HPLC-DAD-MS analyses and grouped by secondary metabolite classes for each plant analised and their means calculated for each population. The letters indicate each location (A. Ibiraci; B. São José da Barra; C. São João Batista do Glória; D. Cocalzinho; E. Capitólio; F. Pirenópolis; G. Delfinópolis)

\begin{tabular}{|c|c|c|c|c|c|}
\hline & & chlorogenic acids & sesquiterpene lactones & $C$-glucosylflavones & flavonoid aglicones \\
\hline & I & 10.9 & 6.3 & 3.8 & 3.1 \\
\hline & II & 10.5 & 6.4 & 3.3 & 5.4 \\
\hline \multirow[t]{6}{*}{ A } & III & 10.8 & 6.5 & 3.5 & 4.1 \\
\hline & IV & 8.3 & 6.6 & 4.4 & 3.4 \\
\hline & V & 9.9 & 5.9 & 4.0 & 4.3 \\
\hline & mean $\pm \mathrm{SD}$ & $10.1 \pm 1.1$ & $6.3 \pm 0.3$ & $3.8 \pm 0.4$ & $4.0 \pm 0.9$ \\
\hline & I & 6.1 & 0.0 & 0.9 & 12.1 \\
\hline & II & 8.8 & 0.0 & 0.4 & 11.8 \\
\hline \multirow[t]{6}{*}{ B } & III & 10.2 & 0.0 & 0.4 & 10.2 \\
\hline & IV & 7.6 & 0.0 & 0.6 & 9.7 \\
\hline & V & 7.6 & 0.0 & 0.4 & 12.6 \\
\hline & mean $\pm \mathrm{SD}$ & $8.1 \pm 1.6$ & $0.0 \pm 0.0$ & $0.6 \pm 0.2$ & $11.3 \pm 1.3$ \\
\hline & I & 3.6 & 0.0 & 0.3 & 13.9 \\
\hline & II & 3.5 & 0.0 & 0.5 & 12.9 \\
\hline \multirow[t]{6}{*}{$\mathrm{C}$} & III & 2.5 & 0.0 & 0.4 & 11.1 \\
\hline & IV & 5.8 & 0.0 & 0.9 & 13.5 \\
\hline & $\mathrm{V}$ & 5.2 & 0.0 & 0.9 & 14.8 \\
\hline & mean $\pm \mathrm{SD}$ & $4.1 \pm 1.3$ & $0.0 \pm 0.0$ & $0.6 \pm 0.3$ & $13.2 \pm 1.4$ \\
\hline & I & 8.1 & 0.0 & 3.8 & 13.2 \\
\hline & II & 9.0 & 0.0 & 4.6 & 10.4 \\
\hline \multirow[t]{6}{*}{$\mathrm{D}$} & III & 10.9 & 0.0 & 5.1 & 9.8 \\
\hline & IV & 4.6 & 0.0 & 3.8 & 12.1 \\
\hline & V & 4.1 & 0.0 & 4.0 & 10.9 \\
\hline & mean $\pm \mathrm{SD}$ & $7.4 \pm 2.9$ & $0.0 \pm 0.0$ & $4.2 \pm 0.6$ & $11.3 \pm 1.4$ \\
\hline & I & 12.7 & 0.0 & 0.6 & 4.5 \\
\hline & II & 11.5 & 0.0 & 0.6 & 5.7 \\
\hline \multirow[t]{6}{*}{$\mathrm{E}$} & III & 11.5 & 0.0 & 1.1 & 5.6 \\
\hline & IV & 11.2 & 0.0 & 0.6 & 5.4 \\
\hline & V & 10.7 & 0.0 & 0.7 & 6.8 \\
\hline & mean $\pm \mathrm{SD}$ & $11.5 \pm 0.7$ & $0.0 \pm 0.0$ & $0.7 \pm 0.2$ & $5.6 \pm 0.8$ \\
\hline & I & 9.8 & 0.0 & 5.8 & 7.9 \\
\hline & II & 10.2 & 0.0 & 6.1 & 7.8 \\
\hline \multirow[t]{6}{*}{$\mathrm{F}$} & III & 7.4 & 0.0 & 3.2 & 6.9 \\
\hline & IV & 8.7 & 0.0 & 6.5 & 6.6 \\
\hline & V & 9.5 & 0.0 & 5.5 & 8.7 \\
\hline & mean $\pm \mathrm{SD}$ & $9.1 \pm 1.1$ & $0.0 \pm 0.0$ & $5.4 \pm 1.3$ & $7.6 \pm 0.9$ \\
\hline & I & 3.3 & 0.0 & 0.5 & 15.4 \\
\hline & II & 3.9 & 0.0 & 0.6 & 13.2 \\
\hline \multirow[t]{4}{*}{ G } & III & 1.5 & 0.0 & 0.5 & 11.7 \\
\hline & IV & 2.1 & 0.0 & 0.7 & 12.6 \\
\hline & V & 3.0 & 0.0 & 0.7 & 14.3 \\
\hline & mean $\pm \mathrm{SD}$ & $2.7 \pm 1.0$ & $0.0 \pm 0.0$ & $0.6 \pm 0.1$ & $13.4 \pm 1.4$ \\
\hline
\end{tabular}




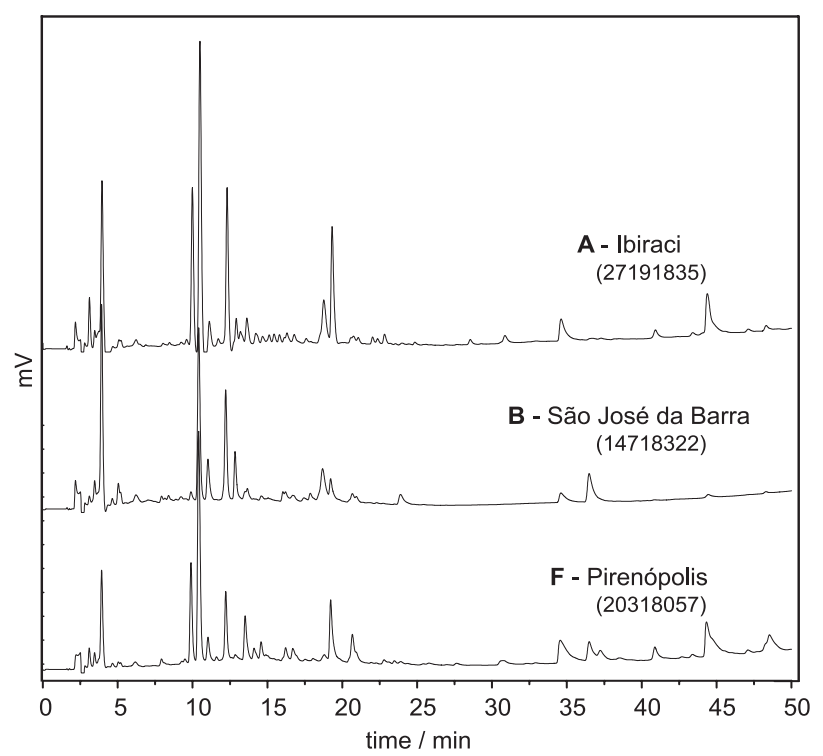

Figure S1. Representative HPLC-ECD (+500 mV) chromatograms obtained for the antioxidant leaf extracts of Lychnophora ericoides from the Ibiraci (A, top), Pirenópolis (F, middle) and São José da Barra (B, bottom) specimens. The number between parentheses represents the total peak area sum (chromatograms obtained at 100,250 and $500 \mathrm{mV}$ ) using the same integration parameters for all the analysis. 